\title{
Measuring the Effective Tax Burden of Lifetime Personal Income
}

\author{
Jan Vlachy"*
}

\begin{abstract}
:
This paper designs and tests a comprehensive model, solved by statistical simulation, which describes and quantifies the effect of the tax system and lifelong income characteristics on the effective tax burden of a population or its segment. In the present application the model is structured and calibrated to analyse the category of employed persons in the Czech Republic. The Czech tax and levy system is shown to be mildly progressive, with a steep digression for very high incomes. It is also shown how the initial income endowment, lifelong income volatility and the minimum wage level impact the structure of effective tax rates, as well as expected unemployment.
\end{abstract}

Key words: Personal income; Lifetime tax burden; Statistical simulation.

JEL classification: $\mathrm{H} 21, \mathrm{H} 24, \mathrm{C} 51, \mathrm{~J} 31$.

\section{Introduction}

One particular impact of tax progression relates to the fact that the effective rate increases for taxpayers with risky income. This phenomenon, which, in the long term, may e.g. impair the disposition of individuals to assume risks and invest in human capital, has been already mentioned by Domar and Musgrave (1944), as well as by Stiglitz (1969), Mirlees (1971), Sandmo (1977) and Kaplow (1995).

A number of researchers, including Ahsan (1973), Eaton and Rosen (1980), Kanbur (1981), Gentry and Hubbard (2000), Schneider and Jelínek (2004), and Arnold (2008), have since focused on various social and behavioural impacts of tax systems and income redistribution. The situation in the Czech Republic has been recently assessed by Friedrich, Maková and Široký (2012), and Klazar, Slintáková (2012), a nonparametric model has been used by Dušek, Kalíšková and Münich (2013). Seidl, Pogorelskiy and Traub (2013) provide a detailed international comparison.

All these authors have either been taking a descriptive microeconomic approach to the problem, or calculated effective or marginal rates as static values, without actually attempting to quantify the incremental taxation of income risk. This requires the setting up of a dynamic model, as implemented in various contexts by Vlachý (2007, 2008a, 2008b), who has used miscellaneous closed-form solutions of a single-step option-based model to assess the tax-liability, an approach initially

Jan Vlachý; Associate Professor, Czech Technical University in Prague, Masaryk Institute of Advanced Studies, Kolejní 2a, Prague 6, Czech Republic; <jan.vlachy@cvut.cz>. 
Vlachý, J.: Measuring the Effective Tax Burden of Lifetime Personal Income.

proposed by Draaisma nad Gordon (1996), and utilized by Sureth (2002), Panteghini (2003) and Niemann (2004), among others.

The purpose of this paper is to develop and assess a comprehensive dynamic model of personal income tax, including the concept of lifetime tax burden, as analysed by e.g. Fullerton and Rogers (1993), with its impact on progression illustrated by Caspersen and Metcalf (1994). The model will be solved for the current personal income tax and levy structure in the Czech Republic.

Broadly, the paper follows up on the papers by Vlachý $(2007,2008 \mathrm{a})$. Contrary to the analytical approach pursued therein, however, it uses parametric statistical simulation (originally considered by Vlachý, 2010, pp. 44-45), which is much more universal in terms of distribution assumptions, as well as embedded feedbacks (Breton and Ben-Ameur, 2005). The model calibrates against relevant published income-distribution data for employed persons in the Czech Republic as of 2014 (MPSV, 2015) and uses the tax and levy structure (i.e. including mandatory social and healthcare levies) applicable to the same population in 2015.

\section{Design and Calibration}

The model combines several factors in its income, i.e. input assumptions. The underlying intertemporal income function is assumed to follow a simple exponential as in (1), where $t$ is the sample's age (in years), $y_{\mathrm{t}}$ the mean expected income of the sample at that age (in CZK).

$$
y_{t}=A_{0} e^{-\frac{\lambda}{t-t_{0}}},
$$

This function has a good fit to empirical data using the parameters $A_{0}, t_{0}$ and $\lambda$ as in Table 1. In the model, individuals (hereafter indexed as $i$ ) are assumed to generate taxable earnings for a total of 41 years (for notation's sake, the years are attributed as representing a person's age 20 through 60 ).

\section{Tab. 1: Calibration parameters}

\begin{tabular}{|l|c|}
\hline$A_{0}$ & CZK 366,000 \\
\hline$t_{0}$ & 13 \\
\hline$\lambda$ & 2.9 \\
\hline
\end{tabular}

\begin{tabular}{|l|c|}
\hline$m$ & CZK 225,720 \\
\hline$s$ & CZK 30,000 \\
\hline$\alpha$ & 0 \\
\hline
\end{tabular}

Source: Author.

Two stochastic functions describe perceived income characteristics within the sample. The first one projects an individual's initial taxable income ${ }^{\mathrm{i}} I_{0}$, assuming a log-normal function taking the form (2), with a non-logarithmized standard deviation $s$, whose non-logarithmized mean $m$ is calibrated to that of the population entering the workforce, and $\varepsilon$ represents a normalized normally distributed random value. 


$$
{ }^{i} I_{0}=e^{\ln \left(\frac{m}{\sqrt{1+s^{2} / m^{2}}}\right)+\sqrt{\ln \left(1+\frac{s^{2}}{m^{2}}\right)}},
$$

The second stochastic function provides for the annual volatility $\sigma$ of an individual's taxable income in time, which is assumed to take the form of logarithmic Brownian diffusion with a floating drift as in (3).

$$
{ }^{i} I_{t}={ }^{i} I_{t-1} e^{\mu_{t}-\sigma^{2} / 2+\sigma \varepsilon},
$$

The value $\varepsilon$ is random, with normalized normal distribution; $\mu$ is annually adjusted by the expected periodical drift derived from (1) as in (4).

$$
\mu_{t}=\frac{\lambda}{\left(t-t_{0}-1\right)}-\frac{\lambda}{\left(t-t_{0}\right)}+\alpha,
$$

The factor $\alpha$ represents a continuously compounded inflation adjustment, which can be used to examine bracket-creep effects. For the current application, it is set at zero. For the sake of interpretation, the reader should note that the volatility measure $\sigma$ includes both a systematic factor (relating to the performance and other characteristics of the economy), as well as a specific factor, pertaining to a particular individual or population segment.

Finally, the model embraces the existence of a minimum wage $I_{\min }$, equal to CZK 110,400 in 2015 (MPSV, 2015). Any particular income ${ }^{\mathrm{i}} I_{\mathrm{t}}$ will thus be realized only in case it reaches this benchmark (i.e. ${ }^{\mathrm{i}} I_{\mathrm{t}} \geq I_{\min }$ ) otherwise the person will become unemployed, with a wage (and thus also en effective tax rate) equal to zero. Instead of actual income, ${ }^{\mathrm{i}} I_{\mathrm{t}}$ should thus be interpreted as an individual's earning potential, or endowment. An alternative setup is possible, that would include the effects of fiscal social transfers (treated as negative taxation).

\section{Results and Discussion}

Different factors can be analysed using the model, including e.g.

- Impact of the income endowment on tax progression;

- Impact of income volatility on tax progression;

- Impact of the minimum wage on unemployment;

- Inflationary effects (bracket creep).

Henceforth, we shall summarize and discuss the most interesting findings of the analysis based on the current problem, i.e. situation of employees in the Czech Republic as of 2015. 
Vlachý, J.: Measuring the Effective Tax Burden of Lifetime Personal Income.

\subsection{The Lifetime Effective Tax Burden as a Function of Income Volatility}

One way of investigating the population characteristics ${ }^{1}$ is through different values of income volatility. An aggregated result of the simulation is shown in Table 2, which summarizes the simulated lifetime effective tax rate $(\tau)$ distribution characteristics, including the mean $\mu(\tau)$ and percentile values ${ }^{\mathrm{P}} \tau$, for different values of income volatility $\sigma$.

\section{Tab. 2: Lifetime Effective Tax Burden Distributions (in \%)}

\begin{tabular}{ccccccccc}
\hline $\boldsymbol{\sigma}$ & $\boldsymbol{\mu}(\boldsymbol{\tau})$ & ${ }^{\mathbf{1 \%}} \boldsymbol{\tau}$ & ${ }^{\mathbf{5 \%}} \boldsymbol{\tau}$ & ${ }^{\mathbf{2 5} \%} \boldsymbol{\tau}$ & ${ }^{\mathbf{5 0} \%} \boldsymbol{\tau}$ & ${ }^{\mathbf{7 5 \%}} \boldsymbol{\tau}$ & ${ }^{\mathbf{9 5} \%} \boldsymbol{\tau}$ & ${ }^{\mathbf{9 9 \%}} \boldsymbol{\tau}$ \\
\hline 5 & 45.04 & 45.00 & 45.00 & 45.00 & 45.00 & 45.00 & 45.31 & 45.86 \\
10 & 45.17 & 45.00 & 45.00 & 45.00 & 45.00 & 45.09 & 46.14 & 46.76 \\
15 & 45.11 & 41.28 & 45.00 & 45.00 & 45.00 & 45.16 & 46.32 & 46.88 \\
20 & 44.93 & 35.52 & 45.00 & 45.00 & 45.00 & 45.21 & 46.25 & 46.75 \\
25 & 44.69 & 30.40 & 42.29 & 45.00 & 45.00 & 45.21 & 46.22 & 46.64 \\
30 & 44.46 & 28.57 & 40.21 & 45.00 & 45.00 & 45.18 & 46.06 & 46.48 \\
\hline
\end{tabular}

Source: Author.

For non-risky earnings (commensurate with the setting of $\sigma=0$ ) simulation shows that the mean tax-payer would be expected to face an effective payroll tax burden of $45.00 \%$.

Somewhat surprisingly, the mean declines slightly with rising volatility above $10 \%$, which is due to a growing proportion (best seen in the first and fifth percentiles) of both high earners (who exceed the social security levy ceiling), and low earners (who become unemployed, paying no tax) in the sample ${ }^{2}$.

Because of this ambiguity, such a breakdown is not very illuminative for insights into the tax burden of particular tax-payer segments. Accordingly, Table 3 lists mean effective tax rates broken down by selected mean annual incomes.

Tab. 3: Mean Lifetime Effective Tax Burden at Different Endowments (in \%)

\begin{tabular}{cccccccc}
\hline $\boldsymbol{\sigma} \backslash \mathbf{I}_{\mathbf{0}}$ & $\mathbf{1 2 0 , 0 0 0}$ & $\mathbf{1 6 8 , 0 0 0}$ & $\mathbf{1 9 2 , 0 0 0}$ & $\mathbf{2 2 5 , 7 2 0} *$ & $\mathbf{3 0 0 , 0 0 0}$ & $\mathbf{4 2 0 , 0 0 0}$ & $\mathbf{6 0 0 , 0 0 0}$ \\
\hline 5 & 43.57 & 45.01 & 45.01 & 45.04 & 45.21 & 45.89 & 46.84 \\
10 & 42.91 & 45.03 & 45.09 & 45.17 & 45.33 & 45.60 & 45.64 \\
15 & 42.23 & 44.99 & 45.09 & 45.11 & 45.09 & 45.07 & 44.57 \\
20 & 41.58 & 44.37 & 44.91 & 44.93 & 44.85 & 44.51 & 43.79 \\
25 & 40.78 & 44.19 & 44.66 & 44.69 & 44.50 & 44.00 & 43.16 \\
\hline
\end{tabular}

1 And conceptually similar to that of Vlachý (2007), who, however, focused on the self-employed and used different methods.

2 The results would differ, if there were no minimum wage, and thus unemployment, as the lowearners would fail to reach the health care levy floor, increasing their effective taxation. This would be relevant for the self-employed, as shown by Vlachý (2008a). 
European Financial and Accounting Journal, 2015, vol.10, no. 3, pp. 05-14.

\begin{tabular}{cccccccc}
\hline $\boldsymbol{\sigma} \backslash \mathbf{I}_{\mathbf{0}}$ & $\mathbf{1 2 0 , 0 0 0}$ & $\mathbf{1 6 8 , 0 0 0}$ & $\mathbf{1 9 2 , 0 0 0}$ & $\mathbf{2 2 5 , 7 2 0} *$ & $\mathbf{3 0 0 , 0 0 0}$ & $\mathbf{4 2 0 , 0 0 0}$ & $\mathbf{6 0 0 , 0 0 0}$ \\
\hline 30 & 39.26 & 43,55 & 44.18 & 44.46 & 44.26 & 43.78 & 42.99 \\
\hline
\end{tabular}

Source: Author.

Note: *Designates actual population mean income.

Counter-intuitively ${ }^{3}$, the populations with low mean annual incomes show declining mean lifelong effective tax rates with higher income volatility. This is due to the fact that such populations (with their earnings endowments close to the minimum wage) are more likely to include life-long unemployed individuals, whose effective tax burden is then $0 \%$.

A similar effect appears with average- and above-average earners at high income volatilities, who have a higher probability of reaching a high-earnings stage and exceeding the social security levy ceiling.

\subsection{The Impacts of Various Factors on Expected Unemployment}

The model can be used to project unemployment rates. As expected, both the mean income level and income volatility increase the projected unemployment rate (Table 4).

Tab. 4: Projected Unemployment Rate (in \%)

\begin{tabular}{cccccccc}
\hline $\boldsymbol{\sigma} \backslash \mathbf{I}_{\mathbf{0}}$ & $\mathbf{1 2 0 , 0 0 0}$ & $\mathbf{1 6 8 , 0 0 0}$ & $\mathbf{1 9 2 , 0 0 0}$ & $\mathbf{2 2 5 , 7 2 0} *$ & $\mathbf{3 0 0 , 0 0 0}$ & $\mathbf{4 2 0 , 0 0 0}$ & $\mathbf{6 0 0 , 0 0 0}$ \\
\hline 5 & 13.78 & 0.67 & 0.15 & 0.02 & 0.00 & 0.00 & 0.00 \\
10 & 27.27 & 8.47 & 5.36 & 2.65 & 0.73 & 0.16 & 0.02 \\
15 & 38.95 & 20.90 & 16.17 & 12.04 & 6.25 & 2.57 & 1.21 \\
20 & 47.82 & 32.49 & 27.82 & 21.94 & 15.06 & 9.29 & 5.04 \\
25 & 56.80 & 42.40 & 37.15 & 32.81 & 24.93 & 17.33 & 12.29 \\
30 & 61.85 & 51,02 & 46.05 & 41.54 & 34.48 & 27.27 & 20.44 \\
\hline
\end{tabular}

Source: Author.

Note: *Designates actual population mean income.

Incidentally, this feature of the model can be used for calibration of the volatility factor, which is otherwise difficult to establish. Its iteration at the actual population's mean income level and unemployment rate suggests a reasonable estimate of $\sigma=12.25 \%$, which is consistent with other possible means of estimating this factor for employees (Vlachý, 2007).

Using this assumption, the model can be used to project expected unemployment rates for various income endowment levels and minimum wage levels, as in Table 5.

3 And in contrast with other authors investigating the same problem using different methods, such as Domar and Musgrave (1944), Mirlees (1971) or Vlachý (2007). 
Vlachý, J.: Measuring the Effective Tax Burden of Lifetime Personal Income.

Tab. 5: Projected Unemployment Rate $(\sigma=12.25 \%)$

\begin{tabular}{cccccccc}
\hline $\mathbf{I}_{\min } \backslash \mathbf{I}_{\mathbf{0}}$ & $\mathbf{1 2 0 , 0 0 0}$ & $\mathbf{1 6 8 , 0 0 0}$ & $\mathbf{1 9 2 , 0 0 0}$ & $\mathbf{2 2 5 , 7 2 0} *$ & $\mathbf{3 0 0 , 0 0 0}$ & $\mathbf{4 2 0 , 0 0 0}$ & $\mathbf{6 0 0 , 0 0 0}$ \\
\hline 110,400 & $32.90 \%$ & $13.34 \%$ & $9.74 \%$ & $6.06 \% * *$ & $2.64 \%$ & $0.88 \%$ & $0.22 \%$ \\
118,800 & $37.67 \%$ & $17.26 \%$ & $11.62 \%$ & $7.35 \%$ & $3.17 \%$ & $1.04 \%$ & $0.25 \%$ \\
122,400 & $39.66 \%$ & $18.66 \%$ & $12.38 \%$ & $8.28 \%$ & $3.43 \%$ & $1.09 \%$ & $0.29 \%$ \\
\hline
\end{tabular}

Source: Author.

Note: *Designates actual population mean income; **Designates current rate of unemployment.

Compared with the current minimum wage, it is shown that expected unemployment would rise upon its recently approved increase to CZK 118,800, as well as the higher proposal of CZK 122,400 by the trade unions. It is also shown that population segments with lower income endowments are disproportionally impacted by the measure. This is an outcome predicted by conventional microeconomics, as well as empirical research (Stigler, 1946; Brown et al., 1982; Neumark et al., 2004; Pícl, Richter, 2014), but the model facilitates its quantification.

\subsection{The Lifetime Effective Tax Burden as a Function of Earnings}

Finally, it is possible to examine the lifetime effective tax rate as a function of mean annual earnings. Results of the simulation are plotted in Figure 1, for a distribution parameterization commensurate with the whole employed population, the current minimum wage, and assumed income volatility of $12.25 \%$.

The chart therein clearly shows that there is a modest progression from $45.00 \%$ for mean annual incomes below approx. CZK 1 million, followed by a relatively steep and convex digression. However, there are outliers (see also the low percentiles in Table 2), representing tax-payers, who will exhibit earnings patterns resulting in a substantially lower tax burden than that implied by their mean earnings ${ }^{4}$.

To compare the results for a different (above-average) earnings segment, Figure 2 illustrates the effective tax burden function for $I_{0}=$ CZK 480,000, falling slightly below the ninth income decile of the benchmark population (MPSV, 2015).

4 Note that the current model design assumes perfect compliance, without any tax-optimization behavior or tax-avoidance. 
European Financial and Accounting Journal, 2015, vol.10, no. 3, pp. 05-14.

Fig. 1: Effective Tax Burden as Function of Mean Income ( $I_{0}=$ CZK 225,720)

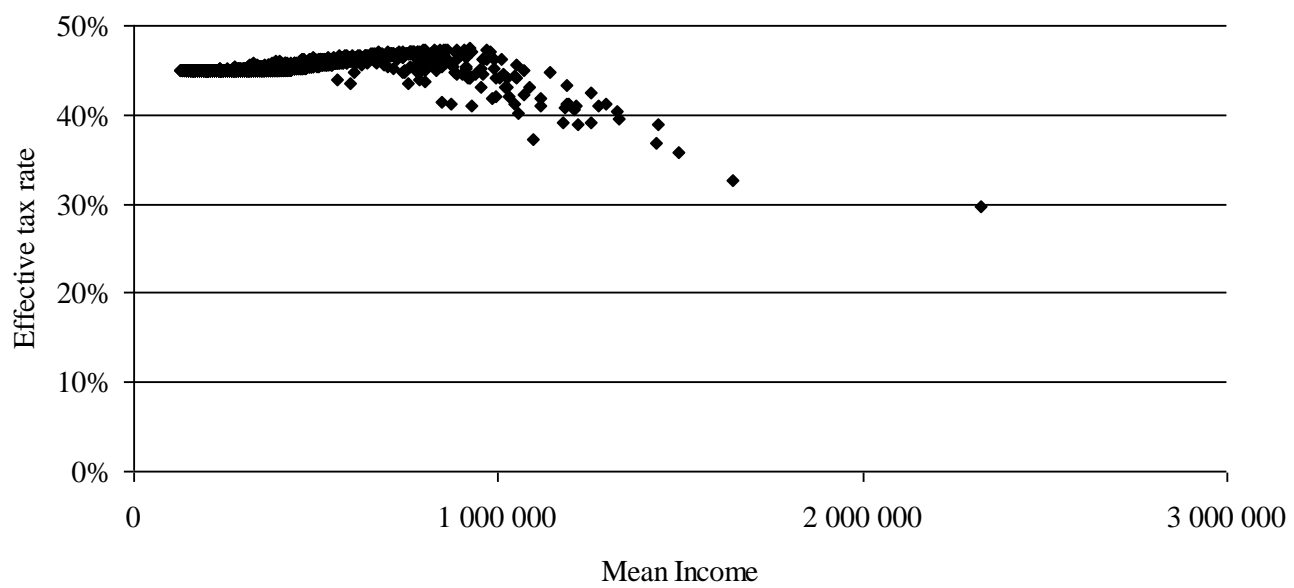

Source: Author.

Fig. 2: Effective Tax Burden as Function of Mean Income (I0 = CZK 480,000)

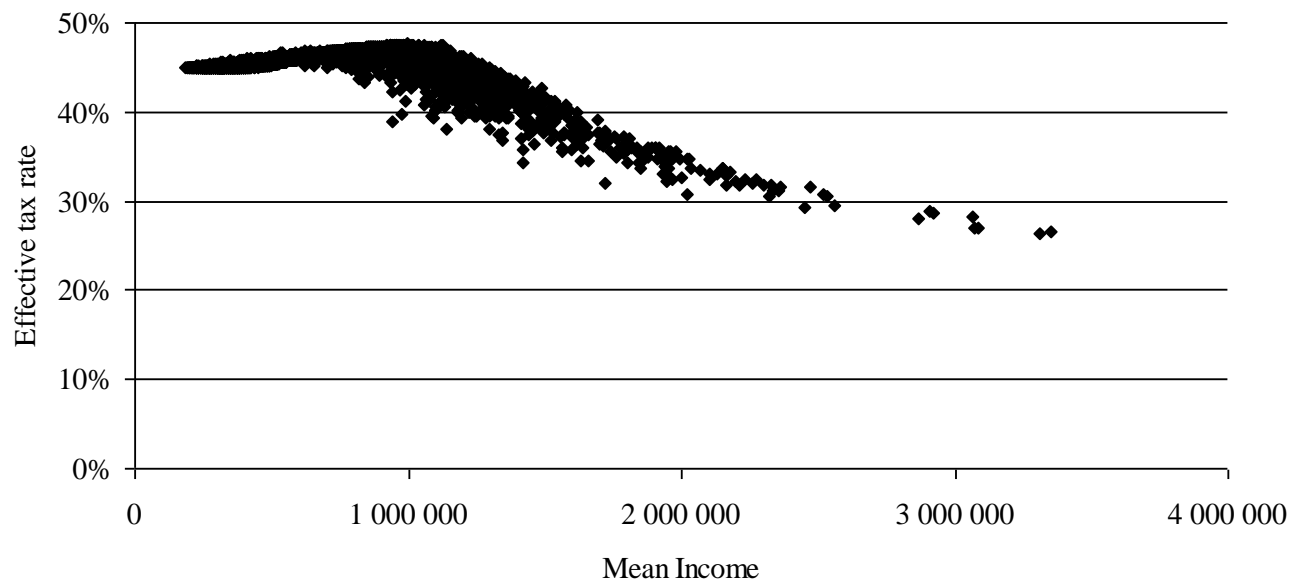

Source: Author. 


\section{Conclusions}

A dynamic simulation-based model has been designed and tested herein, that describes and quantifies the effect of the tax system and lifelong income characteristics on the effective tax burden. Calibrating it to the current tax and levy dues structure and income distribution of employees in the Czech Republic, it is shown that the system, starting from a combined base rate of $45 \%$, is mildly progressive, with a convex digression pattern for distinctly above-average incomes.

Compared to conventional static tax-incidence measurement methods, the model includes intertemporal as well as intersegmential income dynamics, both shortterm and long-term. It is thus shown that the structure of lifelong effective tax rates, and, incidentally, expected unemployment, are primarily driven by the individual's or segment's initial income endowment, lifelong income volatility, as well as the minimum wage level. Surprisingly, increased income volatility need not automatically result in increased effective rates, as normally concluded by authors using microeconomic or single-step derivations, which is due to the evolution of particular longer-term income patterns.

Besides its capacity to conveniently incorporate e.g. alternative distributional assumptions, the simulation method used for analysis is also capable of including behavioural characteristics into the model, such as the use of various taxoptimization or tax-avoidance strategies, or sundry algorithms rendering taxpayers' decisions to enter or leave the workforce.

Interesting opportunities for further research thus include comparative analyses on tax incidence under various fiscal systems on the one hand, as well as analyses of behavioural dynamics driven by different incentive structures and the assessments of their fiscal and redistributional effects on the other hand.

\section{References}

Ahsan, S.M., 1973. Progression and Risk-Taking. Oxford Economic Papers 3, 318-328.

Arnold, J., 2008, Do Tax Structures Affect Aggregate Economic Growth? Empirical Evidence from a Panel of OECD Countries. Working Paper No. 643, OECD, Paris.

Breton, M., Ben-Ameur, H., 2005. Numerical Methods in Finance. Springer, New York.

Brown, C., Gilroy, C., Kohen, A., 1982. The Effect of the Minimum Wage on Employment and Unemployment. Journal of Economics Literature 20, 487-528. 
Caspersen, E., Metcalf, G.E., 1994. Is a Value Added Tax Progressive? Annual Versus Lifetime Incidence Measures. National Tax Journal 47, 731-746.

Domar, E.D., Musgrave, R.A., 1944. Proportional Income Taxation and Risk-Taking. Quarterly Journal of Economics 58, 388-422.

Draaisma, T., Gordon, K., 1996. Valuing the Right to Tax Incomes: An Options Pricing Approach. Working Paper No. 160, OECD, Paris.

Dušek, L., Kalíšková, K., Münich, D. 2013. Distribution of Average, Marginal and Participation Tax Rates among Czech Taypayers: Results from a TAXBEN Model. Finance a úvěr 6, 474-504.

Eaton, J., Rosen, H.S., 1980. Taxation, Human Capital, and Uncertainty. American Economic Review 70, 705-715.

Friedrich, V., Maková, K., Široký, J., 2012. Testing of the Predicative Ability of the Tax Progressiveness Indices. E+M Ekonomie a management 1, 4-16.

Fullerton, D., Rogers, D.L., 1993. Who Bears the Lifetime Tax Burden? Brookings Institution, Washington (DC).

Gentry, W.M., Hubbard, R.G., 2000. Tax Policy and Entrepreneurial Entry. American Economic Review 90, 283-287.

Kanbur, S.M., 1981. Risk Taking and Taxation: An Alternative Perspective. Journal of Public Economics 15, 163-184.

Kaplow, L., 1995. Taxation and Risk Taking: A General Equilibrium Perspective. Woring Paper No. 3709, NBER, Cambridge.

Klazar, S., Slintáková, B., 2012. How Progressive is the Czech Pension Security? Prague Economic Papers 3, 309-327.

Kučera, P., 2015. Minimální mzda má růst nejméně o 700 korun. Hospodářské noviny, 18.5.2015.

Mirlees, J.A., 1971. An Exploration in the Theory of Optimum Income Taxation. Review of Economic Studies 38, 175-208.

MPSV, 2015. Ministerstvo práce a sociálních věcí, Praha. Available from: <http://www.mpsv.cz/cs/3878> [15 June2015]

Neumark, D., Schweitzer, M., Wascher, W., 2005. Minimum Wage Effects throughout the Wage Distribution. Journal of Human Resources 2, 425-450.

Niemann, R., 2004. Tax Rate Uncertainty, Investment Decisions, and Tax Neutrality. International Tax and Public Finance 3, 265-281.

Panteghini, P.M., 2003. A Dynamic Measure of the Effective Tax Rate. Economics Bulletin 15, 1-7.

Pícl, M., Richter, P., 2014. Minimální mzda a její vliv na nezaměstnanost v ČR. Acta Oeconomica Pragensia 6, 51-65. 
Vlachý, J.: Measuring the Effective Tax Burden of Lifetime Personal Income.

Sandmo, A., 1977. Portfolio Theory, Asset Demand, and Taxation: Comparative Statics with Many Assets. Review of Economic Studies 2, 369-379.

Schneider, O., Jelínek, T., 2004. Vliv sociálního a daňového systému na přerozdělování př́ijmů v České republice: Dynamika na přelomu století. Working Paper No. 67, IES FSV UK, Praha.

Seidl, C., Pogorelskiy, K., Traub, S., 2013. Tax Progression in OECD Countries: An Integrative Analysis of Tax Schedules and Income Distributions. Springer, Berlin.

Stigler, G., 1946. The Economics of Minimum Wage Legislation. American Economic Review 36, 358-365.

Stiglitz, J.E., 1969. The Effects of Income, Wealth, and Capital Gains Taxation on Risk-Taking. Quarterly Journal of Economics 2, 262-283.

Sureth, C., 2002. Partially Irreversible Investment Decisions and Taxation under Uncertainty: A Real Option Approach. German Economic Review 2, 185-221.

Vlachý, J., 2007. Dodatečné zdanění osobních př́ijmů v důsledku daňové progrese. Politická ekonomie 5, 625-636.

Vlachý, J., 2008a. Dynamický model zdanění př́ijmů fyzických osob. E+M Ekonomie a management 3, 85-93.

Vlachý, J., 2008b. Assessing Tax Asymmetries and the Incentive to Incorporate. Ekonomický časopis 7, 649-661.

Vlachý, J., 2010. The Value of Tax and Costs of Policy: A Quantitative Study. Lambert Academic Publishing, Saarbrücken. 